\title{
Article
}

\section{Electric Bus Indoor Heat Balance in Cold Weather}

\author{
Gabriel Chiriac ${ }^{1}\left(\mathbb{0}\right.$, Dumitru Dorin Lucache ${ }^{1}\left(\mathbb{D}\right.$, Costică Nițucă $^{1}$, Alin Dragomir ${ }^{2, *}\left(\mathbb{C}\right.$ and Seeram Ramakrishna ${ }^{3}(\mathbb{C}$ \\ 1 Department of Energy Utilisation, Electrical Drives and Industrial Automation, Faculty of Electrical \\ Engineering, "Gheorghe Asachi" Technical University of Iasi, Bd. Dimitrie Mangeron, 21-23, \\ 700050 Iasi, Romania; gchiriac@tuiasi.ro (G.C.); dorin.lucache@tuiasi.ro (D.D.L.); \\ costica.nituca@tuiasi.ro (C.N.) \\ 2 Department of Power Engineering, Faculty of Electrical Engineering, "Gheorghe Asachi” Technical University \\ of Iasi, Bd. Dimitrie Mangeron, 21-23, 700050 Iasi, Romania \\ 3 Department of Mechanical Engineering, College of Design and Engineering, National University of \\ Singapore, 21 Lower Kent Ridge Road, Singapore 119077, Singapore; seeram@nus.edu.sg \\ * Correspondence: alin.dragomir@tuiasi.ro
}

check for updates

Citation: Chiriac, G.; Lucache, D.D.; Nițucă, C.; Dragomir, A.;

Ramakrishna, S. Electric Bus Indoor Heat Balance in Cold Weather. Appl. Sci. 2021, 11, 11761. https://doi.org/ 10.3390/app112411761

Academic Editor:

Luis Hernández-Callejo

Received: 5 November 2021

Accepted: 8 December 2021

Published: 10 December 2021

Publisher's Note: MDPI stays neutral with regard to jurisdictional claims in published maps and institutional affiliations.

Copyright: (c) 2021 by the authors. Licensee MDPI, Basel, Switzerland. This article is an open access article distributed under the terms and conditions of the Creative Commons Attribution (CC BY) license (https:// creativecommons.org/licenses/by/ $4.0 /)$.
Abstract: The use of electric buses is increasing all over the world; this is due to the aim of limiting pollution in heavily urbanized areas. Using electric buses is one element of the desire to drop local pollution to zero emissions. The necessary electricity can be generated through centralized production, and in the case of electric buses, the pollution level is directly proportional to the amount of electricity produced. Their limited onboard power needs optimization, both in terms of traction and in auxiliary energy consumption. Heating in electric buses consumes the most energy from the auxiliaries, which can reduce the range of the vehicle up to a half, or more in the coldest days of the winter months. In this context, a precise estimation of heat loss and of the energy necessary for heating electric buses is crucial. Using the heat transfer theory, the heat balance method, and the U-value estimation, this article estimates the heat loss for a typical $12 \mathrm{~m}$ electric bus for a harsh winter day. Thermal simulations were made in order to estimate the heat flux through the structure of the bus (windows, walls, roof, and floor). Heat loss components were calculated in order to determine the most affected zones of the bus. The calculated data for the energy necessary to heat the bus were compared with the heating system data from an electric bus. By optimizing the necessary auxiliary energy consumption, the emissions at the source of electricity production will be significantly reduced.

Keywords: electric buses heating; heat loss; heat balance method; U-value; thermal modeling

\section{Introduction}

With the accelerated evolution of the development and utilization of electric vehicles, and with many constraints related to energy consumption and environmental pollution, there is more and more research being published related to electric vehicles, giving attention to various goals, such as: reducing energy consumption, improving efficiency for the electric motors, optimizing the auxiliary systems, improving the energy storage capacity, and developing charging system capabilities for the electric vehicles.

Along with these aspects, the thermal comfort of the passengers and drivers, even in extreme conditions, are being studied worldwide, from small electric cars to large electric vehicles, such as electric buses.

Electric buses have many benefits compared with their thermal engine counterparts: they have no emissions and do not pollute the air, they are low noise vehicles and have fewer vibrations, offering superior comfort for the passengers and, importantly, they can use locally produced (and renewable) electric energy.

To make the transition from the conventional engine buses to the electrical ones, authorities and public transport operators have to invest not only in the establishment and development of electric bus fleets but also in new infrastructure. Some countries 
are planning to ban vehicles with thermal engines, while in some cities there are areas considered to be low or zero emission zones. Some cities are part of the C40 Fossil Fuel Free Street Declaration, which promotes the use of only zero emission buses by 2025, asserting that most of the participating cities will use emission-free vehicles by 2030 [1].

More than 1 million buses are used in Europe and around 690,000 buses are in use in the European Union, with the average age of the buses being about 12 years. Thermal engine buses account for more than $94 \%$ of the EU fleet, and less than $2 \%$ are battery electric or hybrid electric buses [2].

Some limitations are still obstructing the expanding use of electric buses, as follows:

- The limited range and power, as compared with conventional thermal buses.

- The necessity of new infrastructures, such as the power grid and systems for battery charging.

- The availability of personnel qualified in technologies different from conventional vehicles, for the maintenance of the electric buses.

There are various types of electric buses, which vary depending on whether electrical energy is generated or stored onboard. Hybrid electric, fuel cell electric, and full battery electric buses are currently being used around the world [3].

Hybrid electric buses use both an internal combustion engine and an electric motor to power the vehicle. Because they have partially a similar technology as traditional engine buses, they are a convenient transition to electric vehicles; however, they raise the same issues as classical vehicles (air pollution and dependence on conventional fuel).

Fuel cells are based on a chemical reaction between stored hydrogen and ambient oxygen to generate electricity. They assure long range and low emissions but are expensive and require a special infrastructure to store the hydrogen and to refuel the vehicles.

Full battery electric buses store all the necessary energy in an onboard rechargeable battery pack. They have no emissions and are energy efficient but have limited distance range and require a charging infrastructure [3].

Moreover, there are various charging systems, such as overnight charging (large size batteries are charged statically from the grid at the depot, mainly during the night, for up to 5-8 h); opportunity charging (medium size batteries are recharged at passenger stopping points or at the bus terminals); or a combination of depot charging and opportunity charging.

Irrespective of the types of electric bus and charging system, the energy from the power source is used for the traction needs and for the auxiliary systems on the vehicle (ventilation, heating, cooling, interior and exterior lights, passenger information devices, ticket vending machines, and others).

The energy required by the auxiliaries could reach up to $35 \%$ of the total energy consumption of the electric vehicle, and, depending on the environment conditionsespecially the external temperature-the non-traction needs could consume up to $50 \%$ of the total energy on vehicles [4], or even up to $70 \%$ in very cold days in winter, when the heating system is used at full power $[4,5]$. Thus, the reduction in energy used for non-traction needs is a main challenge in order to reduce the total energy demand on the electric buses. It is particularly important for battery vehicles, because the batteries-as the energy source-have a limited capacity and limited range [4].

From all the auxiliaries, the heating and cooling consume the most energy-up to $35 \%$ [6]. Moreover, the temperature inside the vehicles depends on the cabin volume: at the same driving conditions, a large vehicle has a different temperature than a small class one. The class of the vehicle, reflected in the quality of the equipment and materials, will also influence the warming and cooling of the vehicle [7].

Conventional vehicles use internal combustion engines, which produce enough waste heat to heat up the vehicle, through the engine cooling circuit via a heat exchanger. Nevertheless, modern thermal engines are more efficient and produce less waste heat; therefore, supplementary electric heaters are necessary to heat the cabin in cold conditions [8].

Electric vehicles use electric motors which generate low amount of waste heat [8]. Even the heat released from the main battery pack is not enough to heat the interior of 
an electric bus, being needed for other heat sources. Therefore, the energy for the heating system is supplied by the power source, the battery pack, which is mainly used for driving and has limited capacity.

The heating has a significant influence over the range of the electric vehicle, reducing the range of the electric vehicle by half, or even more with an external air temperature of $0{ }^{\circ} \mathrm{C}[5]$.

In order to decrease the energy consumption for the HVAC systems on electric buses, several solutions have been proposed, as follows [8-11]: using recovery heat from the traction batteries; an integrated air conditioning and heating system; improved control systems for the heating system; door air curtains/air screened doors to reduce the heat exchange between the inside and outside of the bus [12]; heat pumps; thermal pre-conditioning; complex additional heating equipment. Infrared radiation heating in the vehicle cabin has also been studied for electric vehicles [13,14]. Solid media high-temperature thermal energy storage systems are also being researched for battery electric vehicles [15].

However, many of the above solutions are based on well-known methods, combined with improved strategies for control and optimization.

Therefore, research aiming to improve the heating are in demand for electric vehicles, in order to consume less energy while maintaining passengers' thermal comfort. Thus, new HVAC systems structures and advanced control will bring the best benefits, rather than using advanced cabin materials or increasing thermal isolation [8].

Urban road transportation usually uses technologies adapted from the car industry. In public transportation, where the doors open frequently, allowing passengers to exit and enter the vehicle, it is difficult to ensure a high comfort level. The most common solution for the heating system involves the use of engine cooling water, along with electrical resistance heating [12].

A combined heating configuration composed of zonal air flow and heated surfacesdriver seat, steering wheel, and floor mat-can reduce the heating energy by up to about $28 \%$, while maintaining an equivalent thermal sensation. By simulation, [16] found that the combination of zonal air and surface heating can lead to a $7-19 \%$ improvement of the bus range.

Cabin preheating could also increase an electric vehicle range from $4 \%$ to $10 \%$ for $20 \mathrm{~min}$ of pre-conditioning [8]. There are basically two ways of reducing the power consumption for heating the electric vehicles, as follows: (1) reduction in heating loads and (2) improvement of the thermal system efficiency [8].

The heated load for an electric vehicle includes ventilation load and ambient load. The ventilation load is necessary for two reasons, as follows: the first is to assure the air quality inside the cabin (to keep a low concentration of $\mathrm{CO}_{2}$ ) and the second is to prevent fogging on the windshield and on the other windows [9]. Using recirculated air is a method of reducing the ventilation load, along with using a low thermal conductivity glass for the windshield and windows.

The ambient load is a product of the temperature difference between the cabin air and the external environment, because the heat flows through the vehicle body structure. Some studies on using thermal isolation materials for vehicles showed up to $18 \%$ less heating load. On the other hand, thermal isolation does not always solve the issues, because it can lead to a strong greenhouse effect during the warm days in summer [9].

Zonal heating and inner surface heating (heated seats) are also methods of reducing the heating loads requirements.

In this article, the main goal was to calculate the heat loss for a typical $12 \mathrm{~m}$ electric bus, considering the conditions of a harsh winter day in Romania. Heat loss components were calculated in order to determine the most affected zones of the bus. The analyzed vehicle was actually a trolley bus (supplied from the contact lines), which has been adapted to also operate independently on traction batteries during its route. Due to the limited onboard battery, the distance to be covered as an autonomous vehicle is quite limited, especially in cold weather in winter, when the heating system is in use and the necessary power 
for the heating system is very high (up to $30 \mathrm{~kW}$ ). The goal of our work was to calculate the heat loads inside this specific electric vehicle, with the aim to find the possibilities for optimizing the energy consumption for this type of vehicle.

Thermal simulations were carried out in order to estimate the heat flux through the structure of the bus (windows, walls, roof, floor, and doors). The calculated data for the necessary energy to heat the bus were compared with the heating system data from a real electric bus.

\section{Heat Balance for an Electric Bus}

Optimal energy consumption and interior thermal comfort for the passengers can be calculated and modeled by using heat transfer theory, the heat balance method, and the U-value (thermal transmittance) [17]. Based on the heat transfer theory, there are three mechanisms for transferring heat: conduction, convection, and radiation. Heat transfer into the electric bus is a complicated process, due to the complexity of the vehicle (windows, walls of various layers, floor, roof, and doors) and because all three of the heat transfer mechanisms are present.

\subsection{Heat Conduction}

Conduction appears inside a solid material or between two solid materials and follows Fourier's law for one-dimension, with a temperature gradient inside the material being required for heat transfer. Thus, considering the one dimension as $\mathrm{x}$ direction, $\mathrm{a}$ solid material, for which $\mathrm{k}$ is the thermal conductivity, and for a local thermal gradient of $\frac{d T}{d x}$, the conduction heat flux $\left(q_{c o n d}\right)$ through the material can be calculated with the following equation:

$$
q_{\text {cond }}=-k \frac{d T}{d x}
$$

The heat transfer by conduction in electric buses presents in areas such as the windows, the walls, the roof, the floor, the doors, and any other object inside the vehicle (the seats, for example).

\subsection{Heat Convection}

Convection is an important method of heat transfer for fluids, both inside the fluid and for fluids in contact with solids, and it can be natural or forced convection. Considering the temperature of the fluid $T_{\text {fluid }}$ and the temperature of the body $T_{\text {body }}$, the heat flux resulting from convection can be calculated as shown in Equation (2), where the constant, $h$, is the heat transfer coefficient, as follows:

$$
q_{\text {conv }}=h\left(T_{\text {fluid }}-T_{\text {body }}\right),
$$

Convection in electric buses takes place at the contact between the surfaces of the walls and the fluids such as air (inside the bus) and the air or rainwater (outside the bus). While in the interior the convection has a low variation, on the outside it is amplified with the increase of the bus speed.

\subsection{Heat by Radiation}

Radiation is the only energy transfer mechanism that does not need a material support and depends on the source's temperature and the source's surface properties. For cold bodies, the heat transfer is negligible compared with convection and conduction. Based on the Stefan-Boltzmann law for a black body, this energy emission can be calculated as follows:

$$
q_{\text {rad }}(T)=\epsilon \cdot \sigma \cdot T^{4},
$$

where $\varepsilon$ is the emissivity of the body, $\sigma$ is the Stefan-Boltzmann constant, and $T$ is the temperature of the body [K]. 
The main radiation heat load for a bus is caused by the Sun, and, depending on the weather conditions and the seasons, it can have an important contribution to the heat load balance (during a sunny day at midday) or it may have low impact in heating a bus (during a cloudy and cold winter day).

\subsection{Heat Balance Method for Vehicles}

The heat balance method is a common method for calculating heating and cooling loads in a given space or zone [17]. Based on this theory, all heating loads can be written in a comprehensive equation. Four distinct processes can be assumed for the heat balance into an electric bus, as follows:

1. Outdoor surface heat balance.

2. Indoor surface heat balance.

3. Wall conduction.

4. Inside zone air heat balance.

For an optimal design of the heating system inside the bus, it is crucial to accurately determine the heating loads, because underestimating them may lead to thermal comfort problems, while an overdesign may increase the manufacturing and operating costs for the vehicle [18].

Various heat loads must be considered, but there are eight main heat components to estimate in the modeling and calculation of a vehicle cabin's thermal balance [8,18-20], as follows (Figure 1):

1. Metabolic heat load generated by the passengers- $\dot{Q}_{m e t}$.

2. Solar heat loads (caused by the Sun's radiation) with three components- $\dot{Q}_{\text {sun }}$, as follows:

Direct radiation from the Sun;

Diffused radiation due to the dispersion in the atmosphere;

Reflected radiation from the ground and other surrounding surfaces.

3. Heat load due to the electric motors- $\dot{Q}_{m o t}$.

4. Heat load generated by the traction battery- $\dot{Q}_{b a t}$.

5. Heat load due to the fresh air supplied by ventilation, which is necessary for passengers' needs- $\dot{Q}_{\text {ven }}$.

6. Heat flow changed with the ambient load, due to the temperature gradient between the bus structure (windows, walls, floor, roof, and doors) and the exterior environment- $\dot{Q}_{a m b}$.

7. Heat flow changed with the ambient load, due to the doors opening during stops in stations- $\dot{Q}_{\text {door }}$.

8. Heat load generated by the heating system from the vehicle in order to assure the thermal comfort for passengers- $\dot{Q}_{\text {hsyst }}$.

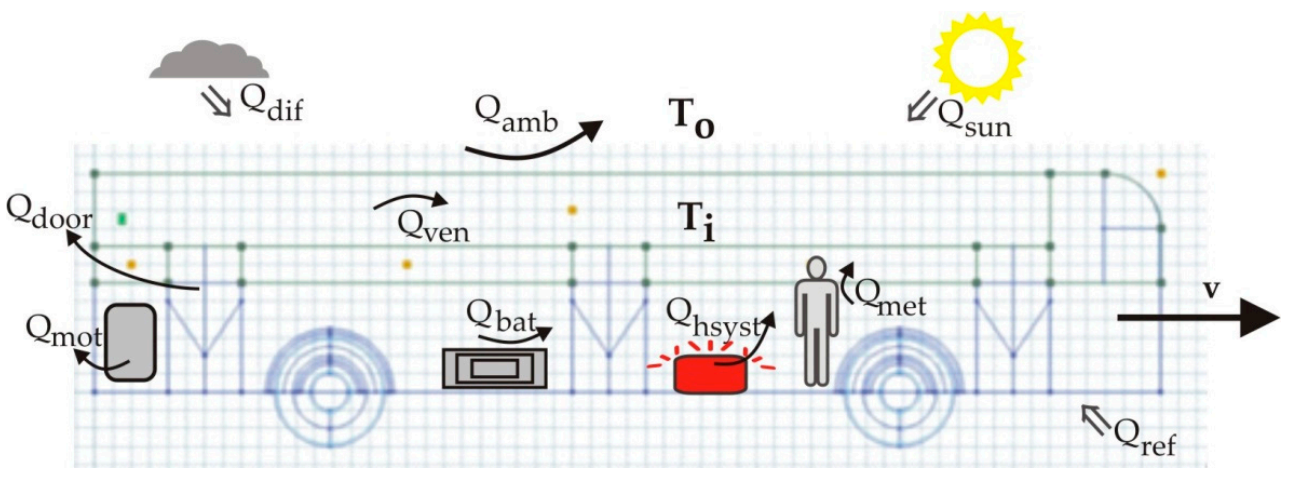

Figure 1. Schematic representation of heat loads: a model for a typical electric bus. 
Thus, considering the above heat components, the heat load model for an electric bus is given by Equation (4):

$$
\dot{Q}_{\text {total }}=\dot{Q}_{m e t}+\dot{Q}_{\text {sun }}+\dot{Q}_{m o t}+\dot{Q}_{b a t}+\dot{Q}_{v e n}+\dot{Q}_{a m b}+\dot{Q}_{\text {doors }}+\dot{Q}_{\text {hsyst }} .
$$

\section{Heat Load Estimation for an Electric Bus}

The necessary power for heating the cabin of the electric buses is estimated in some studies, including $[4,6,21,22]$. According to [6], the energy consumption for heating a bus can reach up to $35 \%$ of the main battery's energy. In [4], data is presented for $12 \mathrm{~m}$ electric buses, with the necessary heating power varying from $5 \mathrm{~kW}$ up to $25 \mathrm{~kW}$ in absolute value, depending on the weather conditions and the time of the day.

In case of resistance heating, the energy demand can, in a worst-case scenario, double or even almost triple the vehicle's energy consumption. From measurements on a $12 \mathrm{~m}$ electric bus, it was estimated that the average electric power necessary to keep the cabin's temperature at $17^{\circ} \mathrm{C}$ on a cold winter day with a $-10^{\circ} \mathrm{C}$ environment temperature was about $24 \mathrm{~kW}$ [21].

Another calculation estimates a heat loss of about $17.4 \mathrm{~kW}$ for a $12 \mathrm{~m}$ length bus, depending on the materials of the vehicle and considering only the thermal conduction through the structure of the bus and the heat loss through the open doors [22].

In this article, for the heat loss estimation, a typical low floor electric bus, with the following characteristics, is considered [23]: $12 \mathrm{~m}$ length, 100 passengers capacity, $150 \mathrm{~kW}$ electric motor, 3 doors, maximum speed $60 \mathrm{~km} / \mathrm{h}$. The heating system of the bus has an installed power of $33 \mathrm{~kW}$ and is composed from 4 heaters of $6 \mathrm{~kW}$ each, used to heat the passengers' cabin, and a $9 \mathrm{~kW}$ heater for the driver's area. The vehicle is operating mainly as a trolley bus (supplied form the contact lines), and it is adapted to operate also independently on traction batteries during its route.

The estimation of the heating loads assumes difficult case conditions of a cold day in winter with a $-10{ }^{\circ} \mathrm{C}$ temperature of the outside environment. Heat loads are calculated for continuous working conditions and the heat load required at first start of the bus was neglected at this stage.

The aim was to estimate the rate of heat to be added inside the vehicle by the heating system in order to maintain the desired conditions for thermal comfort, with a temperature of $20^{\circ} \mathrm{C}$ being considered for the interior of the vehicle. Additionally, the heat loss by its component is to be determined in order to estimate the area consuming the most energy.

\subsection{Metabolic Heat Load Generated by the Passengers, $Q_{m e t}$}

Because passengers of a bus sit and stand, the heat load can be estimated separately, as in [18], with the metabolic heat production rates of $60 \mathrm{~W} / \mathrm{m}^{2}$ and $70 \mathrm{~W} / \mathrm{m}^{2}$, respectively, and with $120 \mathrm{~W} / \mathrm{m}^{2}$ for the driver of the bus. These values are related to the surface area of a person, of about $1.80 \mathrm{~m}^{2}$ [18]. Other authors [24] consider, for the sitting passenger, $55 \mathrm{~W} / \mathrm{m}^{2}$ and $85 \mathrm{~W} / \mathrm{m}^{2}$ for the driver.

Taking into consideration that, during the cold days in winter, the heat released by the human body into the surroundings is limited because the people are dressed in thicker clothes-these thermal values are to be considered for their lower values. Thus, for the calculation, a medium value of $60 \mathrm{~W} / \mathrm{m}^{2}$ is accepted, which, for a person, results in $60 \times 1.8 \mathrm{~m}^{2}=108 \mathrm{~W}$.

Buses are rarely at their full capacity, the average occupancy of a city bus being less than $40 \%$, or even about $30 \%$ [25]; therefore, for the heat load generated by 40 passengers, a $4.32 \mathrm{~kW}$ value is estimated. 


\subsection{Solar Heat Loads- $\dot{Q}_{\text {sun }}$}

\subsubsection{Direct Radiation from the Sun}

Heat gain, due to direct radiation, depends on the direct normal irradiance- - the incident angle of the radiation - on the area and the transmissivity of the surface. The heat gain due to the direct radiation can be estimated as follows [18]:

$$
\dot{Q}_{\text {sunDir }}=A \cdot \tau \cdot I_{\text {Dir }} \cdot \cos (\theta) \quad[\mathrm{W}],
$$

where $A$ is the surface area $\left[\mathrm{m}^{2}\right], \tau$ is the transmissivity of the material, $I_{D i r}$ is the direct normal solar radiation $\left[\mathrm{W} / \mathrm{m}^{2}\right]$, and $\theta$ is the incident angle of the solar radiation.

\subsubsection{Diffused Radiation Due to the Dispersion in the Atmosphere}

This is a heat gain due to the dispersion of the solar radiation on the atmosphere and has specific calculation formula [18], as follows:

$$
\dot{Q}_{\text {sunDif }}=A \cdot \tau \cdot I_{\text {Dif }} \quad[\mathrm{W}],
$$

where $A$ is the surface area $\left[\mathrm{m}^{2}\right], \tau$ is the transmissivity of the material, and $I_{D i f}$ is the diffused solar radiation $\left[\mathrm{W} / \mathrm{m}^{2}\right]$.

\subsubsection{Reflected Radiation Due to the Ground}

In this case, the heat gain is due to the radiation reflected by the ground. Taking into account the winter weather, when the roads are cold, this heat gain is to be considered as negligible for our calculation.

\subsubsection{Solar Heat Gain Estimation for Romania}

Romania is situated in the Central to East European continent area, between $43^{\circ} 37^{\prime}$ and $48^{\circ} 15^{\prime}$ latitude North, and $20^{\circ} 45^{\prime}$ and $29^{\circ} 41^{\prime}$ longitude East, having a temperate continental weather, with about 6 months of cold weather (from October to March). January and December are the coldest months of the year, with average temperatures of about $-6{ }^{\circ} \mathrm{C}$ at midday, with lower temperatures (down to $-10{ }^{\circ} \mathrm{C}$ ) during mornings and evenings, and with minimum temperatures of down to $-24{ }^{\circ} \mathrm{C}$ (based on the official data from the National Meteorological Administration from Romania [26]). During this 6-month period, the solar irradiation to be considered is usually between 9.00 and $15.00 \mathrm{~h}$ of the day (direct radiation load decreases due to the decrease in the sun elevation angle for the simulation period, which happens after midday [24]), having clear sky for about $40 \%$ of the day [27].

The solar heat gain for a bus varies permanently because it depends on a multitude of factors: time of day, clear or covered sky, the angle of incidence of solar radiation, the variable position of the vehicle, the possibility of shading it depending on the route (especially in the urban areas, with boulevards sheltered by high buildings), varying surfaces, and the transparency of the windows, etc. Therefore, the estimation of heat gain from solar radiation can only be carried out roughly, considering several simplifying hypotheses.

Existent data about the solar irradiation in Bucharest, the Romanian capital, during December and January are summarized in Table 1-global irradiation includes measurements for both direct and diffused solar radiation.

\begin{tabular}{|c|c|c|c|c|c|c|}
\hline & \multirow{2}{*}{$\begin{array}{c}\text { Hourly Average of Sun's } \\
\text { Brightness, around } 12 \\
\text { O'Clock }\end{array}$} & Hour & 9 & 12 & 15 & \multirow{2}{*}{$\begin{array}{c}\text { Daily Irradiation } \\
\text { Average, } \\
{\left[\mathrm{W} / \mathrm{m}^{2}\right]}\end{array}$} \\
\hline & & & & $\begin{array}{l}\text { olar Ir } \\
\text { W } / \mathrm{m}^{2}\end{array}$ & & \\
\hline \multirow{2}{*}{ December } & \multirow{2}{*}{0.36} & Clear sky & 89 & 145 & 85 & 106.3 \\
\hline & & Overcast sky & 25 & 68 & 24 & 39.0 \\
\hline \multirow{2}{*}{ January } & \multirow{2}{*}{0.39} & Clear sky & 130 & 280 & 132 & 180.7 \\
\hline & & Overcast sky & 65 & 145 & 68 & 92.7 \\
\hline
\end{tabular}

Table 1. Global irradiation includes measurements for both direct and diffused solar radiation. 
If $H A_{12}$ is the "Hourly average of Sun's brightness, around 12 o'clock", and $I_{g l C}$ and $I_{g l O}$ are the global solar irradiation for the clear sky, respectively, for the overcast sky, then the maximum solar irradiation of the bus happens at noon and can be calculated with the following relation:

$$
I_{M a x}=H A_{12} \cdot I_{g l C}+\left(1-H A_{12}\right) \cdot I_{g l O} \quad\left[\mathrm{~W} / \mathrm{m}^{2}\right],
$$

With the data in Table 1, the above relation shows $I_{\operatorname{Max}}=197.7 \mathrm{~W} / \mathrm{m}^{2}$. However, the solar irradiation of the bus during these two winter months manifests for maximum of $6 \mathrm{~h}$ per day and not all is transformed into the heat. Factors that reduce solar heat inputs, such as the transmissivity of windows, exterior shading, and reflective surfaces, etc., must be taken into account.

The $12 \mathrm{~m}$ bus has a transparent window area of $29 \mathrm{~m}^{2}$, and for a double pane window the transmissivity is $\tau=0.75$ [18]. Keeping the same hourly average of Sun's brightness and applying Relation (7) for the daily average of solar irradiations, the average heat gain is given in Table 2 for both of the winter months considered.

Table 2. Average heat gain for both direct and diffused solar radiation.

\begin{tabular}{|c|c|c|c|c|c|c|}
\hline & $H A_{12}$ & $\begin{array}{l}\text { Average Solar Irradiation, } \\
{\left[\mathrm{W} / \mathrm{m}^{2}\right]}\end{array}$ & $\begin{array}{l}\text { Bus Windows } \\
\text { Area, }\left[\mathrm{m}^{2}\right]\end{array}$ & $\tau$ & $\begin{array}{c}\text { Average Heat } \\
\text { Gain }[k W]\end{array}$ & $\begin{array}{l}\text { Daily Average Heat } \\
\text { Input, }\left[\mathrm{W} / \mathrm{m}^{2}\right]\end{array}$ \\
\hline December & 0.36 & 63.24 & \multirow{2}{*}{29} & \multirow{2}{*}{0.75} & 1.38 & 8.25 \\
\hline January & 0.39 & 126.99 & & & 2.76 & 16.57 \\
\hline
\end{tabular}

The presented calculation is a rough estimation of the heat gain and daily heat input. Contributions of the shading factor or reflected radiation, due to the ground, are neglected. Results showed that the most demanding month for the heating installation is December.

3.3. Heat Flow Due to the Fresh Air Supplied by Ventilation, Which Is Necessary for Passengers' Needs- $\dot{Q}_{\text {ven }}$

Ventilation and ambient loads are functions of the temperature difference between the cabin and the ambient load. The air flow rate for the buses depends on the operating of the air conditioning system, with values between the $0.05 \mathrm{~m}^{3} / \mathrm{s}$ and $0.3 \mathrm{~m}^{3} / \mathrm{s}$ [28]. For the city buses with frequently stops, the fresh air supplied by ventilation is dominated by the air flow through the open doors, and the ventilation can be used for the lower value, which is $0.05 \mathrm{~m}^{3} / \mathrm{s}$ [28]. Heat transfer due to the ventilation can be estimated with Formula (8) and depends on the temperature difference $(\Delta T)$, the specific heat, the air density $\left(\rho_{\text {air }}\right)$ and the air flow rate $(\dot{V})[29]$, as follows:

$$
\dot{Q}_{v e n}=\dot{V} \cdot \rho_{a i r} \cdot c \cdot \Delta T \quad[\mathrm{~W}],
$$

For an air flow rate of $0.05 \mathrm{~m}^{3} / \mathrm{s}$, an air density of $1.27 \mathrm{~kg} / \mathrm{m}^{3}$, a specific heat of $1009 \mathrm{~J} / \mathrm{kg}^{*} \mathrm{~K}$, and a gradient of temperature of $30^{\circ} \mathrm{C}$, the heat transfer due to the ventilation is $\dot{Q}_{\text {ven }}=1.922 \mathrm{~kW}$.

3.4. Heat Flow Changes with the Ambient Load Due to the Temperature Gradient between the Bus Structure and the Exterior Environment (Ambient Heat Load) - $\dot{Q}_{a m b}$

Heat transfer takes place from warm bodies (areas) to colder bodies (areas). So, in the winter cold days, the heat transfer takes place from the heated bus cab to the cold outside environment Thus, a large amount of heat is loss into the atmosphere through the windows, walls, roof, floor, and doors. This heat loss depends on the area of the surfaces, on the heat transfer coefficient (for each material or an overall estimated coefficient), and on the inside and outside temperatures. The heat transfer is estimated considering the conduction through solid materials, the convection between the interior air in the bus and 
the inner surfaces, and the convection between the exterior air and the outer surfaces of the bus (Figure 2).

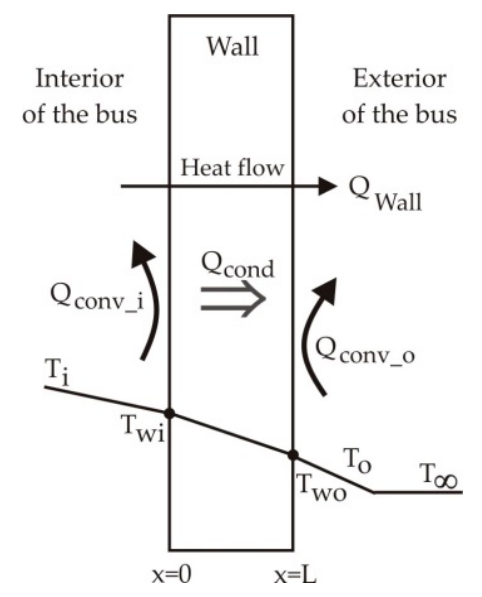

Figure 2. Heat loss through a wall of an electric bus.

For a wall composed by a single layer, the heat transfer is calculated with the following equation:

$$
\dot{Q}=A \cdot U \cdot\left(T_{i}-T_{0}\right) \quad[\mathrm{W}],
$$

where $A$ is the cross-sectional area $\left[\mathrm{m}^{2}\right], U$ is the heat transfer coefficient $\left[\mathrm{W} / \mathrm{m}^{2} \mathrm{~K}\right], T_{i}$ is the inside temperature $\left[{ }^{\circ} \mathrm{C}\right]$, and $T_{o}$ is the outside temperature $\left[{ }^{\circ} \mathrm{C}\right]$,

The heat transfer coefficient is calculated as a combination of conductive and convective heat transfer, which is given by [18]:

$$
\frac{1}{U}=\frac{1}{h_{i}}+\frac{L}{k}+\frac{1}{h_{o}},
$$

where $h_{i}$ is convective heat transfer coefficient between the interior air and the inner surfaces of the wall $\left[\mathrm{W} / \mathrm{m}^{2} \mathrm{~K}\right], h_{0}$ is the convective heat transfer coefficient between the exterior air and the outer surfaces of the wall $\left[\mathrm{W} / \mathrm{m}^{2} \mathrm{~K}\right], \mathrm{L}$ is the thickness of the wall $[\mathrm{m}]$, and $k$ is the conductive heat transfer coefficient of the wall $[\mathrm{W} / \mathrm{mK}]$.

For the vehicles, the convection coefficients of the outer surfaces depend on the vehicle speed, and for the inner space, the coefficient depends on the air speed inside, relative to the inner surfaces [18], as follows:

$$
h=9+3.5 v^{0.66}\left[\mathrm{~W} / \mathrm{m}^{2} \mathrm{~K}\right]
$$

with $v$ as the relative air speed to the surface $[\mathrm{m} / \mathrm{s}]$.

In order to estimate the heat loss as accurately as possible, for the walls composed by multiple layers, the thermal contact resistance between the layers of the bus structure will be considered also. Thus, knowing the heat loss on its components will be possible to estimate the possibilities to improve the bus structure to reduce the heat loss.

With limited information on the roughness profile, the density, and the radii of the contact spots, the estimation of the thermal contact resistance brings uncertainty into the calculation. Considering [30-32], the thermal contact resistance of the interface between two layers is given by the ratio between the difference of temperatures along the interface and the heat, $\dot{Q}[\mathrm{~W}]$, as follows:

$$
R_{c}=\frac{\Delta T_{\text {interface }}}{Q}[\mathrm{~K} / \mathrm{W}],
$$

where $\Delta T_{\text {interface }}$ is the difference of temperature along the layers' interfaces. 
Based on heat flux, $q=\dot{Q} / A\left[\mathrm{~W} / \mathrm{m}^{2}\right]$, related to the surface area, the resistance can be considered as follows:

$$
r_{c}=\frac{\Delta T_{\text {interface }}}{q \cdot A}\left[\mathrm{~K} / \mathrm{m}^{2} \mathrm{~W}\right],
$$

Thus, for a multiple layered wall (with thicknesses $\left(L_{j}\right)$ and conductive heat transfer coefficient $\left(k_{j}\right)$ ), the overall heat transfer coefficient must be calculated, including the thermal contact resistances between the layers, as follows:

$$
\frac{1}{U}=\frac{1}{h_{i}}+\sum \frac{L_{j}}{k_{j}}+\frac{1}{h_{o}}+\sum r_{c j}, \quad\left[\mathrm{~K} / \mathrm{m}^{2} \mathrm{~W}\right],
$$

where $L_{j}$, and $k_{j}$ are the thickness and conductive heat transfer of the layer $j$, and $r_{c j}$ is the thermal resistance for the layer interfaces.

\subsubsection{Heat Loss through the Windows of the Bus- $\dot{Q}_{w}$}

The heat lost through the windows is estimated as heat loss due to conduction through the windows and due to the convection to the interior and exterior air. There are various types of windows used for the buses, differing by glass thickness, the quality of the glass (clearness), or by the types of the windows (one layer or two layers with inside air isolation). For this calculation, it was assumed that the windows have a single layer of $6 \mathrm{~mm}$ glass thickness and the area of the windows of the bus is $29.0 \mathrm{~m}^{2}$.

Using Formulas (8)-(10) and a vehicle speed of $40 \mathrm{~km} / \mathrm{h}(11.1 \mathrm{~m} / \mathrm{s}$ ) (as the maximum speed for the city movement of the bus), the heat loss calculated for the all window area of the bus is $\dot{Q}_{w}=5612 \mathrm{~W}$, for $\mathrm{U}$ value $=6.45 \mathrm{~W} / \mathrm{m}^{2} \mathrm{~K}$.

For the air inside the vehicle, the speed is assumed to be zero, so $h_{i}=9\left[\mathrm{~W} / \mathrm{m}^{2} \mathrm{~K}\right]$, and $k=1.05[\mathrm{~W} / \mathrm{mK}]$ is the conductivity of the glass.

In order to estimate the real temperature on the surfaces of the windows, a simulation using Comsol Multiphysics software has been performed. The simulations were made for the steady-state regime by modeling the geometry of the bus structure and considering the actual values for the parameters of the materials.

Figure 3 shows the thermal simulation through a window of the bus considering an inside temperature of $20^{\circ} \mathrm{C}$ (left side of the image) and an exterior temperature of $-10^{\circ} \mathrm{C}$ (on the right side of the image). The exterior temperature was chosen assuming a difficult case scenario for the month of December in Romania. As can be seen, the temperature on the external side of the glass is of $13.4^{\circ} \mathrm{C}$.

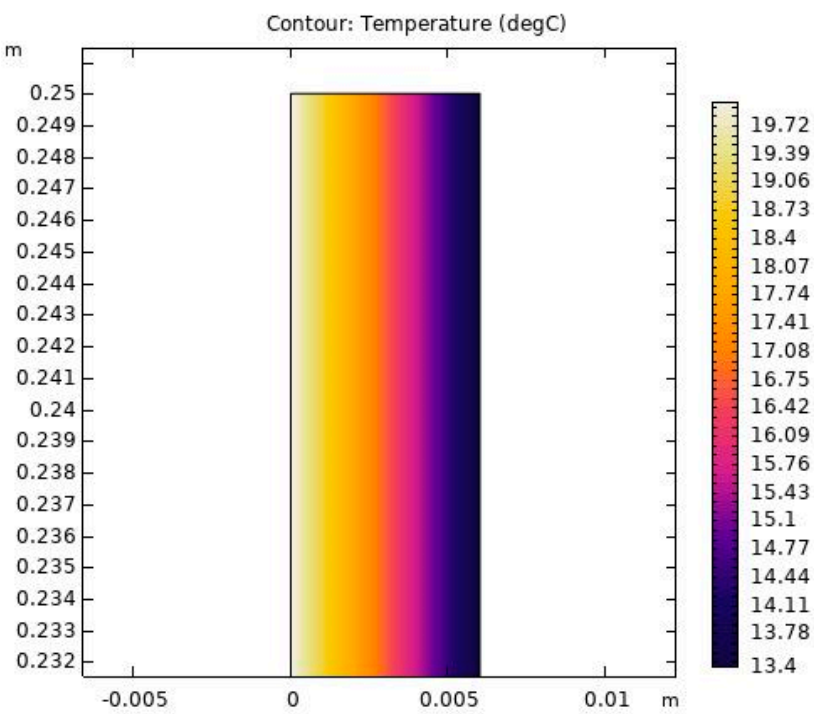

Figure 3. Heat flux variation through the windows of the bus. 


\subsubsection{Heat Loss through the Walls of the Bus- $\dot{Q}_{\text {wall }}$}

The walls of the bus are made from three materials, that is (from inside to outside): laminated wood (MDF), polyurethane foam, and a sheet of steel. Their thickness and thermal conductivities are presented in Table 3.

Table 3. Thickness and thermal conductivities for the materials of the wall of the bus.

\begin{tabular}{ccc}
\hline Material & Thickness $[\mathrm{m}]$ & Thermal Conductivity $[\mathrm{W} / \mathrm{mK}]$ \\
\hline Iron & 0.0008 & 76.2 \\
Polyurethane foam & 0.01 & 0.04 \\
Laminated wood & 0.004 & 0.107 \\
\hline
\end{tabular}

As for the simulation, in Figure $4 \mathrm{a}$, the model of the three layers of the wall is presented, with a temperature of about $-8.1{ }^{\circ} \mathrm{C}$ on the exterior wall of the bus, with main thermal loss from the steel and the foam in the wall. The interior side of the vehicle is on the left side of the image (Figure 4a). Vehicle speed is incorporated into the model as the velocity of the fluid (the exterior air).

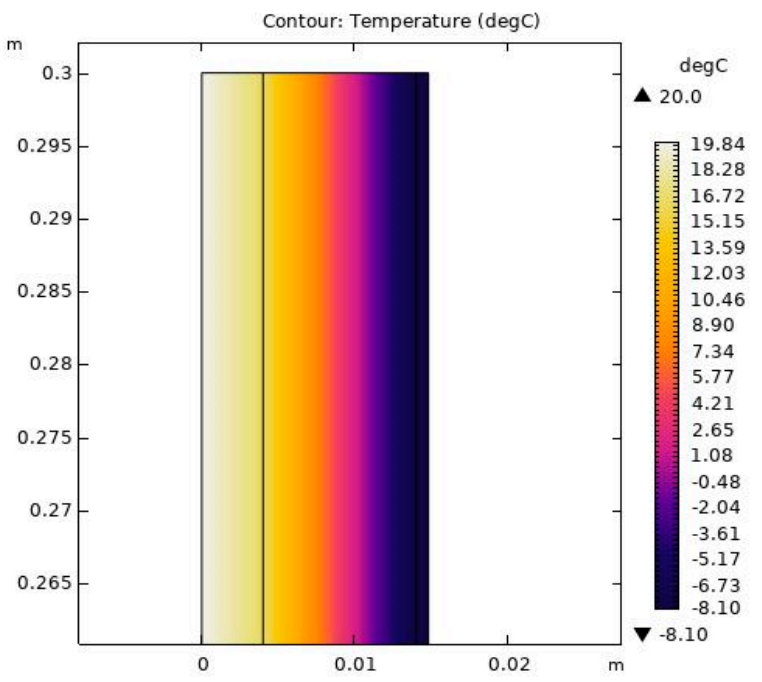

(a)

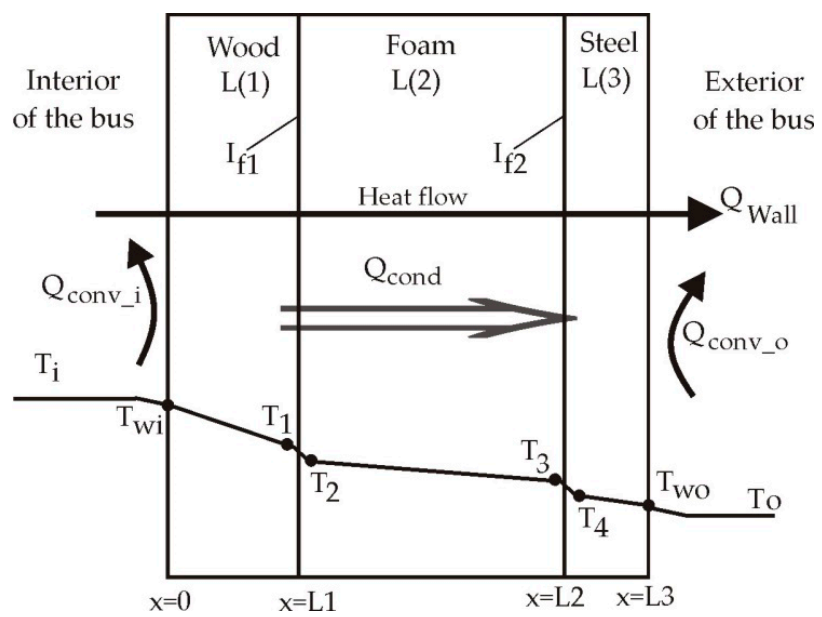

(b)

Figure 4. (a) Heat transfer through the wall. (b) Schema of the three layers of the wall of the bus.

For the triple layered wall of the bus (Figure $4 b$ ), the overall heat transfer coefficient is calculated as follows:

$$
\frac{1}{U_{\text {wall }}}=\frac{1}{h_{i}}+\left(\frac{L_{1}}{k_{2}}+\frac{L_{1}}{k_{2}}+\frac{L_{1}}{k_{3}}\right)+\frac{1}{h_{o}}+r_{\text {cwall }},\left[\mathrm{K} / \mathrm{m}^{2} \mathrm{~W}\right]
$$

The thermal contact resistance for the wall is the sum of the thermal resistance for the two interfaces $\mathrm{I}_{\mathrm{f} 1}$ and $\mathrm{I}_{\mathrm{f} 2}$ (Figure $4 \mathrm{~b}$ ). For the first interface thermal resistance estimation (between the layer of wood, L(1), and foam, L(2)), we assumed that the heat transferred through the surface area of the wall is constant, and we can write the following:

$$
\frac{\dot{Q}}{A}=\frac{\Delta T}{\frac{L 1}{k 1}},
$$

where $\Delta T=T_{i}-T_{1}\left[{ }^{\circ} \mathrm{C}\right]$ is the difference of temperature along the layer, $\mathrm{L}(1)$. 
For the interface zone (between the layers $\mathrm{L}(1)$ and $\mathrm{L}(2)$ ):

$$
\frac{\dot{Q}}{A}=\frac{\Delta T_{\text {interface }}}{r_{c 12}}
$$

$\Delta T_{\text {interface }}=T_{1}-T_{2}\left[{ }^{\circ} \mathrm{C}\right]$, with $T_{1}$ and $T_{2}$ indicating the temperatures on the interface of the layers L(1) and L(2), between wood and foam layers respectively (Figure $4 b$ ).

The interface temperature $T_{1}$ and $T_{2}$ are estimated from the Comsol simulations (Figure 4a), resulting $T_{1}=16.27^{\circ} \mathrm{C}$ and $T_{2}=16.12{ }^{\circ} \mathrm{C}$.

With these values, and using the Equations (16) and (17), the first interface shows $r_{c 12}=0.002\left[\mathrm{~K} / \mathrm{m}^{2} \mathrm{~W}\right]$. Similarly, but considering $T_{3}=-8^{\circ} \mathrm{C}$ and $T_{4}=-8.14^{\circ} \mathrm{C}$, the second interface is calculated, between the second and the third layer, as follows: $r_{c 12}=8 \cdot 10^{-6}$ $\left[\mathrm{K} / \mathrm{m}^{2} \mathrm{~W}\right]$, for the wall of the bus, is $r_{\text {cwall }}=0.00208\left[\mathrm{~K} / \mathrm{m}^{2} \mathrm{~W}\right]$.

For the speed of $40 \mathrm{~km} / \mathrm{h}$, with $20{ }^{\circ} \mathrm{C}$ inside and $-10{ }^{\circ} \mathrm{C}$ outside temperatures, and for an area of the wall of the bus of $A_{\text {wall }}=27 \mathrm{~m}^{2}$, the $\mathrm{U}$ value is determined as $U_{\text {wall }}=2.283 \mathrm{~W} / \mathrm{m}^{2} \mathrm{~K}$ and the heat loss through the wall is $\dot{Q}_{\text {wall }}=1849 \mathrm{~W}$.

\subsubsection{Heat Loss through the Roof- $Q_{\text {roof }}-$ And the Floor of the Bus- $\dot{Q}_{\text {floor }}$}

The roof of the bus is composed of a layer of iron sheet, a layer of polyurethane foam (as isolation), and a volume area filled with various equipment (air conditioning, pipes, power supply equipment, and power conductors from the power collecting system). These equipment elements are made mostly from metals and cover about $50 \%$ of the roof area. Due to this complex structure of the roof, in order to estimate the $U$ value for the roof, including this complex area (composed of metals materials and air), we consider this area as composed of two parallel layers of metals and air.

The simulation of the heat transfer through the roof is presented in Figure 5a, which shows the differences in temperatures between the metal area of the third layer (on the left) and the air area (on the right of the third layer).

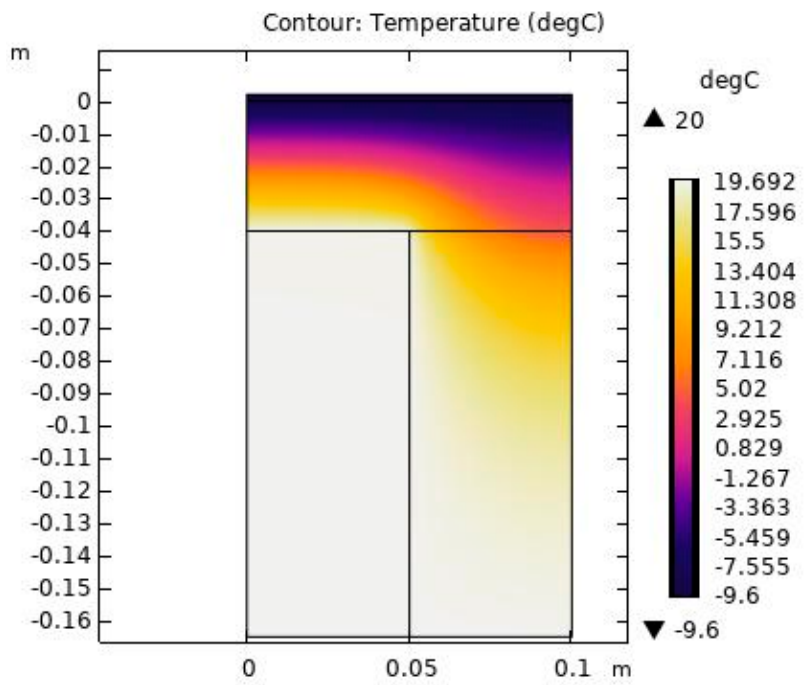

(a)

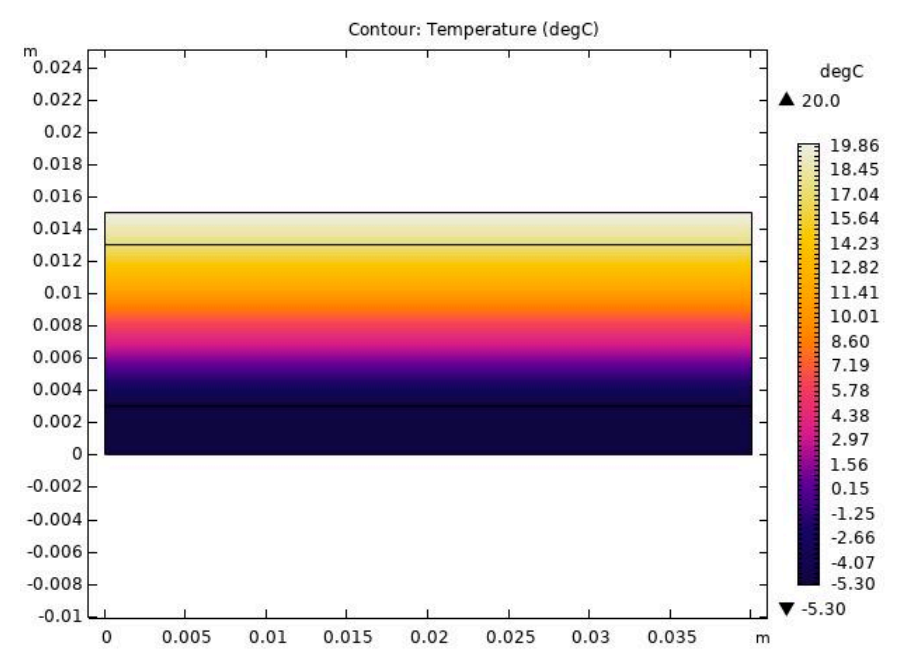

(b)

Figure 5. (a) Heat transfer through the roof of the bus. (b) Heat transfer through the floor of the bus.

For the speed of $40 \mathrm{~km} / \mathrm{h}$ a $\mathrm{U}$ value for the roof of $1.87 \mathrm{~W} / \mathrm{m}^{2} \mathrm{~K}$, the heat loss is $\dot{Q}_{\text {roof }}=1632 \mathrm{~W}$. This calculation include also the thermal resistance of the roof layers $\left(r_{\text {croof }}=0.008\left[\mathrm{~m}^{2} \mathrm{~K} / \mathrm{W}\right]\right)$.

The floor is composed of three layers: an iron sheet, a laminated wood layer, and a PVC layer for the intensive transport of people (Table 4). The U value (at $40 \mathrm{~km} / \mathrm{h}$ ) for the 
floor (including thermal resistance $r_{\text {cfloor }}=0.0152\left[\mathrm{~m}^{2} \mathrm{~K} / \mathrm{W}\right]$ ) is $2.747 \mathrm{~W} / \mathrm{m}^{2} \mathrm{~K}$ and the heat loss is $2425 \mathrm{~W}$.

Table 4. The thicknesses and thermal conductivities for the materials of the floor of the bus.

\begin{tabular}{ccc}
\hline Material & Thickness $[\mathrm{m}]$ & Thermal Conductivity [W/mK] \\
\hline Iron & 0.002 & 76.2 \\
Laminated wood & 0.02 & 0.107 \\
Polyvinyl/PVC & 0.003 & 0.19 \\
\hline
\end{tabular}

The total heat loss through the windows, walls, roof, and floor of the bus, for a speed of $40 \mathrm{~km} / \mathrm{h}$, is determined as $\dot{Q}_{a m b}=11,518 \mathrm{~W}$.

The total ambient heat loss (heat loss through the windows, walls, roof, and floor of the bus) is presented in Table 5 for the various speeds of the vehicle $(0,20,40$, and $60 \mathrm{~km} / \mathrm{h}$ ) These values show a significant variation of heat loss between the moment when the bus stops and when it is in motion. It is worth mentioning that the influence of the thermal resistances is less than $3 \%$. Moreover, the differences of heat loss between various speeds are not too high: they are about $3-5 \%$.

Table 5. $\mathrm{U}$ values and heat loss through the bus structure into the ambient.

\begin{tabular}{|c|c|c|c|c|c|c|c|c|c|}
\hline \multirow{2}{*}{$\mathbf{v}[\mathbf{k m} / \mathbf{h}]$} & \multicolumn{4}{|c|}{ U Value $\left[\mathrm{W} / \mathrm{m}^{2} \mathrm{~K}\right]$} & \multicolumn{4}{|c|}{$\dot{Q}$ Structure [W] } & \multirow{2}{*}{$\dot{Q} a m b[\mathrm{~W}]$} \\
\hline & Uw & Uwall & Uroof & Ufloor & $\dot{Q} w$ & $\dot{Q} w a l l$ & $\dot{Q}$ roof & $\dot{Q}$ floor & \\
\hline 0 & 4.4 & 1.957 & 1.67 & 2.272 & 3832 & 1585 & 1458 & 2004 & 8879 \\
\hline 20 & 5.988 & 2.218 & 1.828 & 2.66 & 5209 & 1797 & 1595 & 2346 & 10,947 \\
\hline 40 & 6.45 & 2.283 & 1.87 & 2.747 & 5612 & 1849 & 1632 & 2425 & 11,518 \\
\hline 60 & 6.757 & 2.32 & 1.89 & 2.8 & 5878 & 1879 & 1653 & 2470 & 11,880 \\
\hline
\end{tabular}

\subsection{Heat Loss Due to the Doors Opening}

Estimating the heat loss through the open doors of the bus when it is stopped in stations is quite difficult, due to the air flow complexity between the inside of the bus and the exterior air of the environment, which depends on the random process of the weather conditions and wind speed and direction. The air is assumed to be an ideal gas and is compressible.

When a pressure is applied to the interior air, the volume of the air is modified with a volume equal to the amount of the outside air, which is pressurized into the vehicle cabin, and therefore an air exchange is caused in the process. Some of the income air from outside is mixed with the inside air and is removed through the opening of the doors, due to the airflow direction change and due to the gradient of the temperature and the pressure, this is proportional to the surface area of the opening [33].

The worst-case scenario is when the wind blows directly into the open door, as presented into the cross-section of the bus structure, showing an opened door (Figure 6).

The heat loss through an open door of the bus is estimated with the following formula:

$$
\dot{Q}_{\text {door }}=\dot{V} \cdot \rho_{\text {air }} \cdot \mathcal{c} \cdot \Delta T[\mathrm{~W}],
$$

where $\dot{V}$ is the flow rate of the air $\left[\mathrm{m}^{3} / \mathrm{s}\right], \rho_{\text {air }}$ is the air density $1.27 \mathrm{~kg} / \mathrm{m}^{3}$, and $c$ is specific heat of the air $1009 \mathrm{~J} / \mathrm{kg} \cdot \mathrm{K}$. 


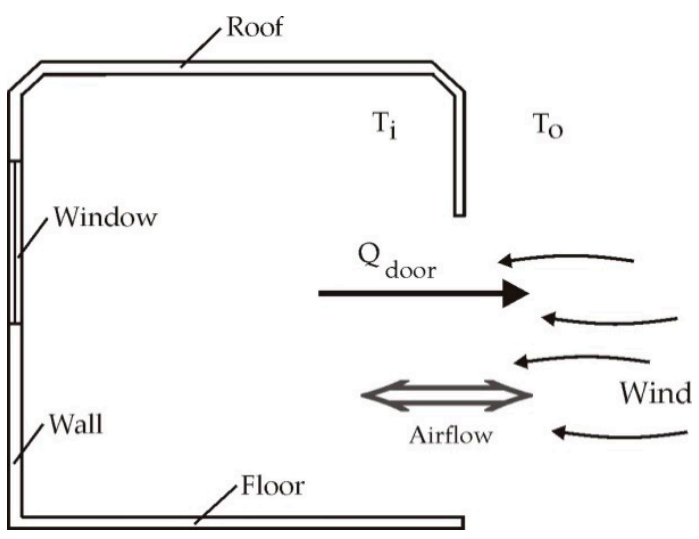

Figure 6. Schema cross-section through the bus structure for an open door.

According to [33], for a single opening enclosure (one open door), for a wind velocity of $10 \mathrm{~m} / \mathrm{s}$ (a medium wind speed value during a cold day in winter), a flow rate of $\dot{V}=0.4 \mathrm{~m}^{3} / \mathrm{s}$ for a surface area of $1.44 \mathrm{~m}^{2}$ is found. Thus, using Formula (17), heat losses result of $\dot{Q}_{\text {door }}=15,377 \mathrm{~W}$ for a single open door and, respectively, of $\dot{Q}_{3 d o o r}=46,131 \mathrm{~W}$ for all the three open doors of the bus,

Obviously, usually the doors do not stay open too frequently. The average stop time for a city bus is about $30 \mathrm{~s}$ [21], with an average running time between stops of $4 \mathrm{~min}$, resulting the doors being open for $1 / 9 \mathrm{~h}$. As consequence, the hourly heat loss from the open doors is $5.125 \mathrm{~kW}$. Depending on the route, the number of stops, and the number of passengers getting on and off the vehicle, this heat loss may have various values.

\subsection{Heat Load Due to the Electric Motors and Heat Load Generated by the Traction Battery}

The actual electric vehicles use high efficiency electric motors which generate low amount of waste heat [8]. Even the heat released from the main battery pack is not enough to heat the interior of an electric bus, and for the present calculation of the heat inside the bus these heat losses are considered as negligible.

\subsection{Heating System Load to Assure the Thermal Comfort for Passengers}

Summarizing the heat loads on the bus, a heat gain of $5.72 \mathrm{~kW}$ (the sum of $\dot{Q}_{m e t}$ and $\dot{Q}_{s u n}$ ) and a loss of energy of $18.5 \mathrm{~kW}$ (the sum of $\dot{Q}_{v e n}, \dot{Q}_{a m b}$, and $\dot{Q}_{d o o r s}$ ) is found. As consequence, the necessary load for the heating system of the 12-m long bus is about $12.79 \mathrm{~kW}$. For higher speeds (max. $60 \mathrm{~km} / \mathrm{h}$ speed of the bus) and for even harsher winter conditions, this value grows up to $14 \mathrm{~kW}$. This load has to be compensated by the heating system, regardless of the technology used to heat the bus [31].

The analysed existent bus is equipped with 4 heaters of $6 \mathrm{~kW}$ in the passengers' cabin and 1 heater of $9 \mathrm{~kW}$ in the driver's area. This results in $33 \mathrm{~kW}$ of power installed for the electric bus heating system, which, compared with our model, is an oversized heating system $[34,35]$. The oversizing is only useful for more quickly obtaining the ambient comfort parameters in the bus.

\section{Discussion}

Research on heating in vehicles is of major importance, especially in cold weather zones, but it is not wide spread over all types of vehicles. Most studies are in the area of automobiles, with few on buses, due to the fact that analyzing and simulating a bus (which is significantly larger and has an intricate structure) is a more complex and timeconsuming process.

This article aimed to respond to some of the thermal problems related to electric buses. Estimation of the necessary heat to assure thermal comfort during cold winter days is quite important due to the limited power of these types of electric vehicles. Additionally, 
along with the limits in energy stored onboard and the vehicles complexity, their particular operating regime results in a complex study due to the various numbers of passengers, doors frequently opening, and the necessity to operate throughout the day.

This study estimates the eight main heat load components on electric buses. Two of them were assumed to be negligible for our thermal model. Firstly, the heat load due to the electric traction motor, and secondly that due to the traction battery pack, as the actual elements are highly efficient.

Therefore, six heat loads were considered for our model: metabolic heat load, Sun heat load, ventilation heat load, ambient heat load, heat flow through the open doors, and the heat load generated by the heating system in the bus. These heat loads were calculated for a $12 \mathrm{~m}$ electric bus with the following characteristics: 100 passengers, $150 \mathrm{~kW}$ electric traction motor, 3 doors, and $33 \mathrm{~kW}$ installed power for the heating system. The calculation was estimated for a harsh winter cold day of December in Romania, with a median temperature of $-10{ }^{\circ} \mathrm{C}$. The thermal comfort of the passengers was calculated for a $20^{\circ} \mathrm{C}$ temperature inside the bus, resulting a gradient of temperature of $30^{\circ} \mathrm{C}$.

The value of the metabolic heat load depends on the passenger numbers in the vehicle, and the Sun heat load depends strongly on the weather conditions. These heat loads are as a contribution (a heat gain) to the inside bus heating (considered as positive in the thermal model of the vehicle), and, for a harsh day in winter, these represent about $22 \%$ and less than $15 \%$, respectively, of the necessary heat of the bus. The heat load from ventilation is an energy-consuming heat load (with energy supplied from the onboard storage system) and it represents less than $10 \%$ of the necessary heat for the bus. Being a mandatory system in the vehicle, its contribution to the vehicle heating can be considered to be a heat gain. Thus, these three heat loads assure an input of heat of about $23 \%$ of the necessary heat inside the bus.

Heat loss on the bus is composed of the ambient heat loss through the bus structure and the heat loss through the open doors at the stops, with an average value of energy demand of $12-14 \mathrm{kWh}$. Of these, through the bus structure the heat loss is the most significant, with its four components-the windows, the walls, the floor, and the roofrepresenting about $78 \%$ of the total heat loss. The main heat loss is through the windows (about 26\%), while the other three heat loss components have almost the same contribution (about $8.1-8.3 \%$ each).

Heat loss through the open doors depends on the route of the bus, the number of stops, and the number of passengers getting on and off the vehicle, with an estimation of $22 \%$ of the total heat loss.

The heat load balance led to the conclusion that the heating system must supply a minimum heat load of $18.5 \mathrm{~kW}$. This value is useful for more successfully designing the heating system and managing its operation. The thermal model used in this study allows optimization of the process, by using various less frequently studied heating solutions in order reduce the energy consumption for the heating, and implicitly reduce the $\mathrm{CO}_{2}$ footprint, while preserving the thermal comfort of the passengers and driver.

Author Contributions: Conceptualization, G.C.; methodology, G.C. and D.D.L.; software, G.C.; validation, G.C., D.D.L. and C.N.; formal analysis, D.D.L. and A.D.; writing—original draft preparation, G.C.; writing-review and editing, A.D.; visualization, A.D. and S.R.; supervision, D.D.L. and S.R.; funding acquisition, G.C. and C.N. All authors have read and agreed to the published version of the manuscript.

Funding: This research and the APC were funded by "Gheorghe Asachi" Technical University of Iasi, Romania, grant number GI/P 9_Idei/2021.

Institutional Review Board Statement: Not applicable.

Informed Consent Statement: Not applicable. 
Conflicts of Interest: The authors declare no conflict of interest. The funders had no role in the design of the study; in the collection, analyses, or interpretation of data; in the writing of the manuscript, or in the decision to publish the results.

\section{References}

1. Transport \& Environment. Electric Buses Arrive on Time. Campaigning for Cleaner Transport in Europe. 2018. Available online: https:/ / www.transportenvironment.org/discover/electric-buses-arrive-time/ (accessed on 8 October 2021).

2. ACEA-European Automobile Manufacturers' Association. Report-Vehicles in Use, Europe 2021. 2021. Available online: https:/ / www.acea.auto/publication/report-vehicles-in-use-europe-january-2021/ (accessed on 8 October 2021).

3. MRC_Electric_Bus_Report_28082017-Electric Bus Technology Transport Research Report. 2017. Available online: https: / / www.coursehero.com/file/48912037/MRC-Electric-Bus-Report-28082017pdf (accessed on 8 October 2021).

4. Bartłomiejczyk, M.; Kołacz, R. The reduction of auxiliaries power demand: The challenge for electromobility in public transportation. J. Clean. Prod. 2020, 252, 119776. [CrossRef]

5. Oi, H.; Tabata, K.; Naka, Y.; Tochihara, Y. Effects of Regional Heating by Heated Seat in Vehicles on Thermal Sensation at $15{ }^{\circ} \mathrm{C}$. J Hum.-Environ. Syst. 2012, 14, 31-39. [CrossRef]

6. Evtimov, I.; Ivanov, R.; Sapundjiev, M. Energy consumption of auxiliary systems of electric cars. MATEC Web Conf. 2017, 133, 06002. [CrossRef]

7. Simion, M.; Socaciu, L.; Unguresan, P. Factors which influence the thermal comfort inside of vehicles. Energy Procedia 2016, 85, 472-480. [CrossRef]

8. Lajunen, A.; Yang, Y.; Emadi, A. Review of Cabin Thermal Management for Electrified Passenger Vehicles. IEEE Trans. Veh. Technol. 2020, 69, 6025-6040. [CrossRef]

9. Zhang, Z.; Wang, D.; Zhang, C.; Chen, J. Electric vehicle range extension strategies based on improved AC system in cold climate-A review. Int. J. Refrig. 2018, 88, 141-150. [CrossRef]

10. Kang, B.H.; Lee, H.J. A review of recent research on automotive HVAC systems for EVs. Int. J. Air-Cond. Refrig. 2017, 25, 1730003. [CrossRef]

11. Marshall, G.J.; Mahony, C.P.; Rhodes, M.J.; Daniewicz, S.R.; Tsolas, N.; Thompson, S.M. Thermal management of vehicle cabins, external surfaces, and onboard electronics: An overview. Engineering 2019, 5, 954-969. [CrossRef]

12. de Lieto Vollaro, R. Indoor climate analysis for urban mobility buses: A CFD model for the evaluation of thermal comfort. Int. J. Environ. Prot. Policy 2013, 1, 1-8. [CrossRef]

13. Bauml, T.; Dvorak, D.; Frohner, A.; Simic, D. Simulation and measurement of an energy efficient infrared radiation heating of a full electric vehicle. In Proceedings of the 2014 IEEE Vehicle Power and Propulsion Conference (VPPC), Coimbra, Portugal, 27-30 October 2014; pp. 1-6.

14. Collins, D.; Rednic, R.; Thake, C.D. Infrared heating as an adjunct to achieve vehicle occupant thermal comfort. Extrem. Physiol. Med. 2015, 4 (Suppl. S1), A82. [CrossRef]

15. Dreißigacker, V. Solid Media Thermal Energy Storage System for Heating Electric Vehicles: Advanced Concept for Highest Thermal Storage Densities. Appl. Sci. 2020, 10, 8027. [CrossRef]

16. Jeffers, M.A.; Chaney, L.; Rugh, J.P. Climate control load reduction strategies for electric drive vehicles in cold weather. SAE Int. J. Passeng. Cars-Mech. Syst. 2016, 9, 75-82. [CrossRef]

17. Sahraei, H. Interior Climate U-Value Calculation and Optimization for Electric Buses at Volvo Buses. Master's Thesis, Department of Mechanics and Maritime Sciences, Chalmers University of Technology Gothenburg, Gothenburg, Sweden, 2020. Available online: https:/ / odr.chalmers.se/bitstream/20.500.12380/300921/1/2020-39\%20Hamidreza\%20Sahraei.pdf (accessed on 9 December 2021).

18. Tanyeri, N.; Başlamişli, Ç. Prediction of the annual heat load of an articulated electric urban bus. Isı Bilimi Tek. Derg. 2020, 40, 27-36.

19. Torregrosa-Jaime, B.; Bjurling, F.; Corberan, J.M.; Di Sciullo, F.; Paya, J. Transient thermal model of a vehicle's cabin validated under variable ambient conditions. Appl. Therm. Eng. 2015, 75, 45-53. [CrossRef]

20. Pedersen, C.O.; Fisher, D.E.; Liesen, R.J. Development of a Heat Balance Procedure for Calculating Cooling Loads. ASHRAE Trans. 1997, 103 Pt 2, 459-468.

21. Göhlich, D.; Fay, T.-A.; Jefferies, D.; Lauth, E.; Kunith, A.; Zhang, X. Design of urban electric bus systems. Des. Sci. 2018, 4, e15. [CrossRef]

22. Chiriac, G.; Lucache, D.D.; Nituca, C.; Gabor, G. Aspects regarding the heating of electric buses. In Proceedings of the 13th International Conference on Electromechanical and Energy Systems (SIELMEN), Iasi, Romania, 7-8 October 2021.

23. Nițucă, C.; Chiriac, G.; Gabor, G.; Nucă, I.; Cazac, V.; Burduniuc, M. Geometry Design and Analysis of an Electric Bus for the Interior Thermal Modelling. J. Energy Technol. 2021, in press.

24. Fayazbakhsh, M.A.; Bahrami, M. Comprehensive Modeling of Vehicle Air Conditioning Loads Using Heat Balance Method; Technical Paper 2013-01-1507; SAE International: Warrendale, PA, USA, 2013.

25. Yildirim, K.-E.; Finkenrath, M.; Gökoglu, M.; Seidel, F. Monitoring the Fresh-Air Flow Rate for Energy-Efficient Bus Ventilation. In Energy and Thermal Management, Air Conditioning, Waste Heat Recovery; Junior, C., Jänsch, D., Dingel, O., Eds.; Springer International Publishing: Cham, Switzerland, 2017; pp. 147-156. 
26. National Meteorological Administration of Romania. Available online: https://www.meteoromania.ro/clim/caracterizarelunara/index.html (accessed on 29 October 2021).

27. Balan, M. Energii Regenerabile. Ed UT PRES. 2007. Available online: http://www.termo.utcluj.ro/regenerabile (accessed on 9 December 2021). (In Romanian).

28. Pirouz, B.; Mazzeo, D.; Palermo, S.A.; Naghib, S.N.; Turco, M.; Piro, P. CFD Investigation of Vehicle's Ventilation Systems and Analysis of ACH in Typical Airplanes, Cars, and Buses. Sustainability 2021, 13, 6799. [CrossRef]

29. Gis, M.; Wiśniowski, P.; Bednarski, M. Efficiency of electric vehicle interior heating systems at low ambient temperatures. Open Eng. 2021, 11, 499-507. [CrossRef]

30. Bejan, A.; Kraus, A.D. (Eds.) Heat Transfer Handbook; John Wiley \& Sons: Hoboken, NJ, USA, 2003; Volume 3.

31. Fang, W.-Z.; Gou, J.-J.; Chen, L.; Tao, W.-Q. A multi-block lattice Boltzmann method for the thermal contact resistance at the interface of two solids. Appl. Therm. Eng. 2018, 138, 122-132. [CrossRef]

32. Wang, A.; Zhao, J. Review of prediction for thermal contact resistance. Sci. China Technol. Sci. 2010, 53, 1798-1808. [CrossRef]

33. Haghighat, F.; Rao, J.; Fazio, P. The influence of turbulent wind on air change rates-A modelling approach. Build. Environ. 1991, 26, 95-109. [CrossRef]

34. Vaswani Reyes, R.H. Optimization of the Heating System of a Bus Cabin: A Numerical Approach through OpenFOAM. Master's Thesis, Politecnico di Torino, Torino, Italy, 2020. Available online: https://webthesis.biblio.polito.it/15401/ (accessed on 8 December 2021).

35. Henning, M.; Smyth, A.; Thomas, A. An Analysis of the Association between Changes in Ambient Temperature, Fuel Economy, and Vehicle Range for Battery Electric and Fuel Cell Electric Buses. Technical Report; Urban Publications. 0123 1630. 2019. Available online: https: / / engagedscholarship.csuohio.edu/urban_facpub/1630 (accessed on 9 December 2021). 